\title{
委員会統合，及び分子接合技術
}

\section{Integration of Committees and Molecular Bonding Technology}

材料技術・環境調和型実装技術委員会

\section{1. 材料技術委員会と環境調和型実装技術委員会の統合}

材料技術は，エレクトロニクス実装分野でも重要な役割 を担っており, 電子機器の高性能化や高機能化, 製造プロ セスの改良など世の中の要求に基づき，常に新しい技術が 開発されている。これまで材料技術委員会では, 材料に対 するニーズの調査とともに，電子材料やプロセス材料，製 品応用, さらにはそれらを支える基礎化学工学に関する研 究活動を進めてきている。

一方, 世の中の電子機器に対する要求の中では, 持続可 能な社会の構築のために環境調和という視点が不可欠であ り, 実装材料の削減やプロセスの短縮, エネルギ変換効率 の向上のためのパワーデバイス, 低消費電力化設計, 新環 境法, 規制, 鉛フリー化やハロゲンフリー化などもその一 例といえる。環境調和型実装技術委員会では, これら注目 技術に関わる研究活動を紹介してきた。

しかしながら俯瞰して捉えれば，エレクトロニクス実装 学会に㧍いて材料技術, 環境調和技術ともに用途横断的な 役割を持ち，また両委員会の研究領域は近づいてきてお り，参加している委員や団体も重複している状況である。 これら状況を踏まえ, 近い領域を違う視点で活動していた 両委員会を 2017 年度に正式に統合し, 相乗効果, 効率化, および活性化を図ることにした。2016年度に両委員会の統 合について議論し, 尽力, 賛同して頂いた委員, 関倸者に は感謝を申し上げたい。

統合後はこれまでの両委員会および研究会の研究活動内 容を踏襲し, ニーズや革新的新規技術について関連団体や 関連企業と連携して各種調查研究活動を行い, 新技術の方 向性・指針を探るとともに, 公開研究会, 非公開研究会を 開催し, 関連工業技術の活性化に寄与している。

なお，委員会名については，2017年度は暫定的に両委員 会の名称を合わせた形になっているが， 1 年間議論し， 2018 年度に相応しい新たな委員会名に変更する予定である。

\section{2. 䩣新的なものづくりプロセスと高付加価値を生み 出す分子接合技術}

接合技術は人類の進化と共に，また人類の営みと共に生 活の道具および製品を作る過程で多数・多種類が使われて きた。その歴史は古いが，現在は機械的接合技術，溶接接 合技術，および接着剤接合技術に分類される接合技術が主 にものづくり分野の加工・組み立て工程で使用されてい る。機械的な接合技術は木材や繊維素などの天然物を用い て人類が最初に使用した接合技術であり, 生活のために使 用され，時代の進化と共に民生技術から工業技術に高度化 および巧緻化されて現在に至っている。溶接接合技術は紀 元前 3000 年前頃から人類の活動範囲や種類の拡大により, 鍛接, リベット接合， ロウ付けなどとして使われた証拠が 見られるが，溶接接合技術の幕開けは産業革命までまたな ければならない。金属を溶融させて接合する技術は 19 世紀 初期に入ってから多くの溶接技術が開発され産業の発展に 寄与した。接着剤接合は前者の二つと同様に, 人類が道具 の使用するころから天然物を用いて行なわれてきたが，幕 開けは 1926 年ヘルマン・シュタウデインガー1)による高分

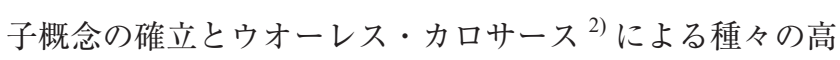
分子化合物の合成, ポール・フローリーの高分子化合物の 特性解明が基点となり，マリリン・モンローがナイロンの 靴下を履いて，その美しさと強さを強調した映画で高分子 時代がはじけたと考えている。20世紀初期から中期にかけ ての出来事であるが，現在では，上記各種の接合技術がな くてはならない不可欠のものづくりのッールとして重要な 位置付けに扔かれている。しかしながら, 同時に, 従来技 術では解決できないものづくり分野や部品および性能・コ ストの点で不満を脱し切れないでいる。特に接着剤接合に おいては合理的な接合理論の構築が未達成であり, 多数の 事例の存在 ${ }^{3), 4}$ にもかかわらず，山積する接合の課題を解 決できないでいる。

接着剂接合は, 図 1 (a)のように主に分子間力や水素結合 などの二次結合力によって界面結合力を発現する。界面結 


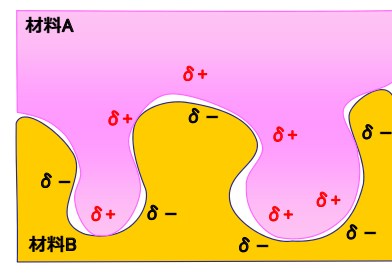

（a）アンカー効果による接合

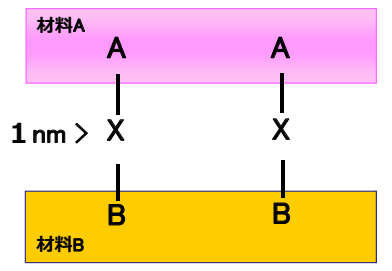

(b) 分子接合による接合
図 1. 密着のメカニズム
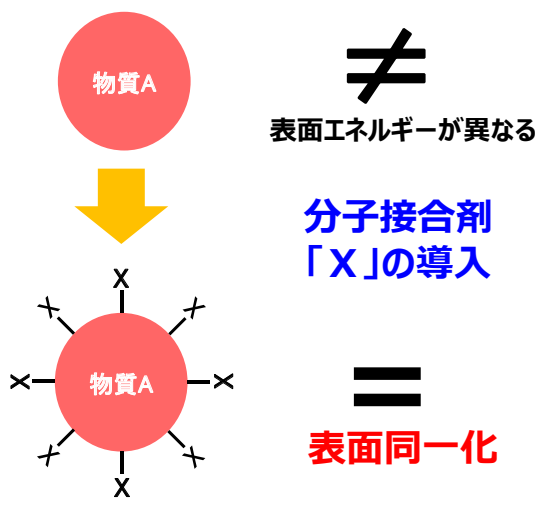

物質B

\section{分子接合剂 $\lceil X 」$ 導入}

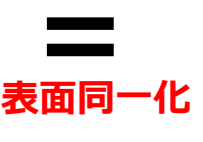

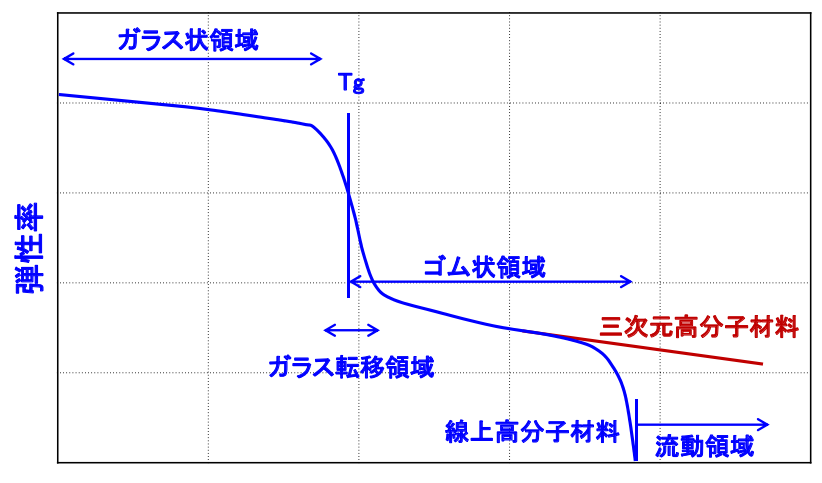

温度

することを「分子接合技術による表面同一化」と呼んでい る（図 2)。共有結合は，通常の接着剂と被着体に働く二次 結合力よりも大きいので，十分な界面結合力を得ることが でき，平滑な界面を確保できるとともに，環境が変化した 場合でも信頼性を確保できる。

接合技術において, 最も重要な因子は被着体と接着体間 の接触である。接触せずして材料間の接合は成立しない。 接着剂接合掞いて，接触は主として「濡れ現象」に依存し ているが，分子接合技術に扔いては反応性，接触圧，抒上 び温度の協同効果を利用している。図 3 は高分子材料にお ける弾性率と温度の関係 (変形温度依存性), および分子接 合技術の接合範囲を示している。分子接合技術においては 被着体と接着体間で十分な接触を得るために, 線状高分子 材料のガラス転移温度 $(\mathrm{Tg})$ 以上の温度で接触・接合を行 なっている。従来，金属と樹脂のインサート射出接合おい て, 樹脂の主転移温度（融点：Tm）以上で溶融成形してい たが，分子接合技術では $\mathrm{Tg} \sim \mathrm{Tm}$ の温度範囲でも界面反応 が起こるので接合が可能となる。このように線状高分子材 料の場合の接合を流動体分子接合と呼んでいる。これに対 して，3 次元高分子材料のように変形は起こるが，流動し ない三次元高分子材料の場合は $\mathrm{Tg}$ 以上の温度で加工圧（例 えば，プレス圧）による接触が可能となるので接合する。 この場合を非流動体分子接合と呼んでいる。非流動体材料 は 3 次元材料であるので一般に接合しがたい材料であるこ とから，分子接合技術の固有の特徴であると云える。

\section{3. 実装分野における応用展開}

\section{1 フレキシブルプリント配線板（FPC）への応用 ${ }^{6)}$}

プリント配線板の密着強度が発現するメカニズムは, 銅 箔のマット面形状，または樹脂表面の粗化によって形成さ れる凹凸を利用したアンカー効果，拉よび分子間力や水素 結合の二次結合力で得ている。しかし，凹凸があることで 高精細パターンの形成が阻害され，表皮効果の影響による 高周波の伝送ロスが拡大する弊害も多い。

これらの課題を解決するために，分子接合技術を用いて 


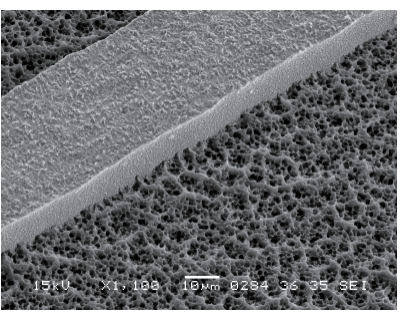

(a) 一般 FPC

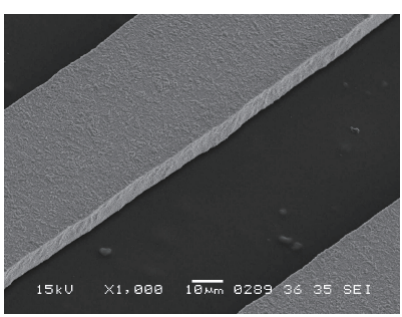

(b) 新規 FPC
図 4. FPC の回路パターンの SEM 像

ポリイミドフィルム上へのダイレクトメタラズに応用し, 高性能, 安価で革新的な両面 FPC を開発, 製品化を実現し ている。

一般的な両面 FPC は, フレキシブル銅張積層板を用いる が，分子接合技術を用いたプロセスは，ポリイミドフィル ムにダイレクトにメタライズをするので，一般プロセスに 比べ材料の削減, プロセスの短縮化が可能である。また, 新規 FPC はベース銅箔がないことから, 一般 FPC に比べ 全体で約 $2 / 3$ に薄くできる。

一般 FPC および新規 FPC の回路パターンの SEM 像を図 4 に示す。一般 FPC は銅がエッチングされた表面に銅䇴の アンカーが転写された凹凸が見られるが, 新規 FPC は平滑 なポリイミドの表面を維持している。加えて, 導体厚を薄 くできることもあり，高精細パターンを容易に形成できる。 銅張積層板を必要としないこと, 従来プロセスと比較し て工程を簡素化できること，銅䇴がないことからドリル工 程での重ね枚数が増えることやドリル寿命が延びること， および容易な回路形成による歩留り向上によりコスト低減 が見込める。

新規 FPC は一般 FPC に比べ，導体の表面粗さが小さい ことから, 高周波領域での表皮効果による伝送損失を低減 できる。さらに，ポリイミドより誘電率と誘電正接が低 く, 伝送損失を低減できる液晶ポリマーや低コスト高分子 材料を使ったメタライジング技術も確立している。

実装分野の超ファインパターン形成にはスパッタリング によるシード層形成が採用されている。スパッタリングは 薄膜形成という面では優れているが, 真空プロセスため設 備コスト, 生産性の面で課題がある。分子接合技術を用い た無電解めっきは，スパッタリングの代替として極薄で表 面モフォロジーと導電性の良好なシード層形成が可能であ り, 超ファインパターン形成, 生産性向上, 低コスト化が 可能である。また, 分子接合剤には紫外線領域で有機材料 と化学結合をするものがあり, 被着体に部分的に分子接合 剂の結合, 無電解めっきをすることによりレジストを使わ ないダイレクトパターン形成も可能である（図 5)。

今後は, 分子パターニング, 分子実装という分野が次世 代の実装技術をリードすると考えられる。

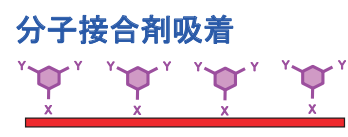

紫外線露光

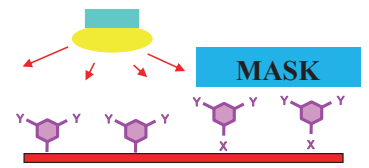

洗浄

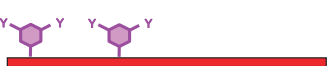

触媒付与
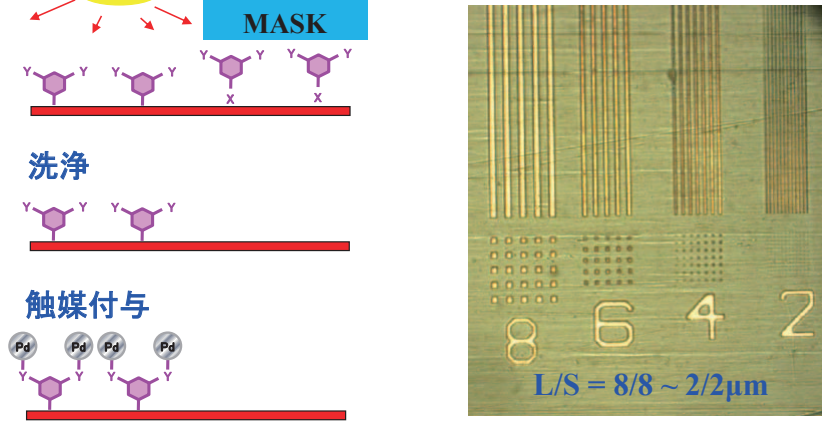

図 5.レジストを使わないダイレクトパターン形成

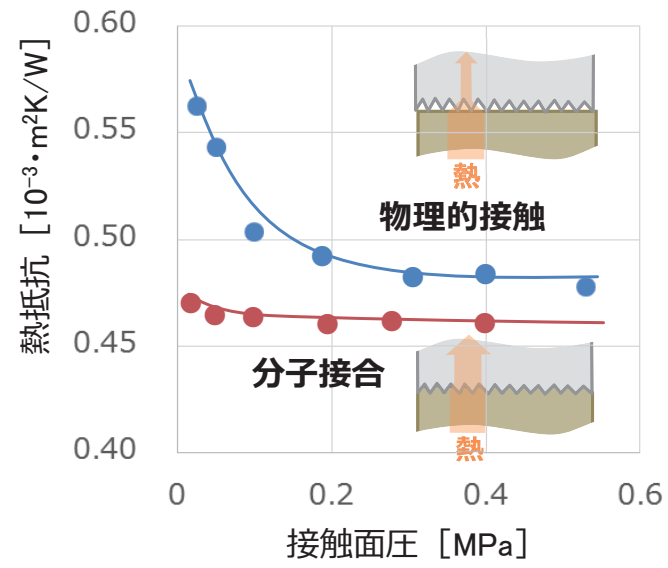

図 6. 物理的接触と分子接合の熱抵抗

\section{2 放熱分野での応用}

熱対策は，エレクトロニクス実装では共通の課題であ り,さらなる放熱性能の向上，合わせて信頼性の確保が求 められ，材料の熱伝導率だけではなく，異種材料の界面に 発生する接触熱抵抗も考慮して設計する必要がある。

熱は固体中では自由電子または振動の形で伝導する。分 子接合技術は材料間に共有結合を形成させることができる ため，材料間で振動を効率よく伝えることができる。たと えば，熱源と放熱フィンがサーマルインターフェイスマテ リアル (TIM) を介して接合されていると, 熱源と TIM 間, TIM と放熱フィン間の熱伝導効率は悪く，いわゆる接触熱 抵抗の寄与が大きくなる。さらに，TIM は無機物の放熱 フィラーと有機物のマトリックス樹脂からなっており，そ れらの界面にも接触熱抵抗が生じる。これらの界面を分子 接合させることで製品全体の熱伝導を改善することが可能 となる。

図 6 にアルミニウム/シリコーンゴム/アルミニウムか らなる積層品の物理的接触と分子接合の熱抵抗の圧力依存 
性を示している。圧力のみで密着させた物理的接触の場 合, 圧力の低下に従い急激に熱抵抗が増加する。これは, 圧力が低下することで接触面積が低下するためである。一 方, 分子接合の場合, 熱抵抗が低く, ほぼ一定の值を示し ている。これは, 接合する際に加えた圧力により, 測定時 の圧力がなくても共有結合により接触面積が維持されてい るためである。また，十分な圧力下においても分子接合し た方が熱抵抗は低く, 界面の化学結合が熱を振動として伝 えていることが示唆された。分子接合を用いることで材料 間の熱抵抗が低減される上，これまでTIM を密着させるた めに必要だった機械的な圧力構造が不要になり, 新たな構 造設計が可能になる。

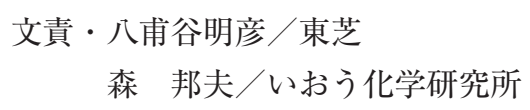

\section{文献}

1) H. Staudinger: “Hermann Staudinger zum 80," Gebutstag, Heidelberg, 1961

2) M. E. Hermes: "Wallace Carothers," American Chemical society and the chemical heritage foundation, Washington D. C, 1996

3）倉田 崇：“先端接着接合技術,”明誠企画, 2000 年 10 月

4) 田崎裕人：“樹脂一金属接着・接合部の応力解析と密着性の 耐久性評価, ”後術情報協会, 2014 年 9 月

5) 森 邦夫：“21 世紀の接着技術一分子接着剂一, ” 日本接着 学会誌, Vol. 44, No. 6, pp. 242-248, 2007

6）八甫谷明彦, 他：“革新的なモノづくりプロセスと高付加価 值を生み出す分子接合技術, ”東芝レビュー, Vol. 70, No. 6, pp. 44-47, 2015

八甫谷明彦（はっぽうや あきひこ）

森 邦夫（もりくにお） 